\title{
The Visibility of the Invisible: Potentials of Wrapping Leaves in the Livelihood of Rural Women of Ekiti State, Nigeria
}

\section{Gladys Modupe, Kayode ${ }^{1 *}$ and Joshua, Kayode ${ }^{2}$}

\section{Abstract}

The study identified plant species whose leaves are used for wrapping food and agricultural products in Ekiti State, Nigeria, and determined their economic potentials to rural women. Semi-structured questionnaire matrix was used to interview randomly selected women. The interviews were focused, conversational and two-way in communication. Nineteen indigenous food and nine agricultural products were enfolded in the study area. Wrapping leaves were obtained from seven plant species. Leaves harvestings were predatory and annihilative in two of these speciesMegaphrymium macrostachyum and Thaumatococcus daniellii- that were not cultivated in the study area. Leaves from $T$. daniellii were the preferred for wrapping and has a market value. Women dominated the harvesting, products utilization, haulage and marketing of the leaves of this species. In addition, women were familiar with the habitat and ecology of the species. Thus, it offers an opportunity to rural women in order to improve their economic status.
${ }^{1}$ Department of Adult Education and Community Development, Ekiti State University, Ado-Ekiti, Nigeria ${ }^{2}$ Department of Plant Science and Biotechnology, Ekiti State University, AdoEkiti, Nigeria

${ }^{1}$ gladys.kayode@eksu.edu.ng

Keywords: Wrapping leaves, rural women, Megaphrymium macrostachyum, Thaumatococcus daniellii 


\section{INTRODUCTION}

Wrapping is a form of packaging, a science, art and technology of enclosing or protecting a product for distribution, storage, sale and use. Such products include food and agricultural products (Kabuo et. al., 2015). Wrapping food helps retain their nutritional value and/or flavour for a longer period (Abdulmumeen et. al., 2012) and thus eliminate microorganisms from the food and prevent their growth. Similarly, packaging play vital role in food production, this includes physical protection, barrier protection from oxygen and water vapour, reducing security risk during shipment and creating convenience in distribution, handling sales, opening, use and reuse (Robertson , 2005). The type of packaging materials used in agricultural products help in defining the quality of the products (IFT, 1991, Muncke, 2009). Thus, packaging can be described as a coordinated system of preparing goods for transport, warehousing, logistics and sales (Fieider, 1995).

Food and agricultural products need to be protected against biodegrading agents such as pests, fungi, bacteria and nematodes. This is important in order to increase their shelf lives as pests easily infect most of them, some easily breakup and this leads to their destruction, which make them unfit for human use. Similarly, a host of environmental factors, such as heat and the presence of microorganisms are known to act and change food stuffs in ways that may harm the food and agricultural products and make them unacceptable for consumption (Daniel, 2007). Therefore, the need for their preservation is highly imperative.

The use of plant leaves constitute a veritable aspect of the traditional packaging system, particularly in rural areas. The use of plants for wrapping over synthetic packaging materials is receiving more attention nowadays; this is because plants were found to be natural and cheaper. They are holistic in nature, easy to get and does not need the presence of skilled personnel before they could be utilized (Karthikeyan et. al., 2009, Schmidt, 2017). Modern packaging preservative methods such as cellophane, nylon, foils and the use of refrigerators and freezers for preservation are often beyond the reach of resource-poor rural dwellers, even when such equipment are available, electricity to power them is not available in the rural areas. So that, a sustainable approach to improve the shelf lives of foods and agricultural products is still limited to traditional methods.

Previous assertion revealed that rural women in Nigeria maintained special relationships with their environment (Kayode, 2006). This enables them to have sound knowledge of the plant products used in household economy. The women served as the primary collectors of these products which include fodder, fuel wood, drugs, fruits and wrapping leaves (Carr, 


\section{Original Article}

2008). Women are also responsible for food preparation, haulage (from farms) and sales of agricultural products (usually in towns and cities).

Recent studies revealed that wrapping leaves, like other non-wood forest products, are now important trading commodities at local, national, regional and international levels (Tieguhong and Ndoye, 2004; Endamana et. al. 2016; Ojea et. al. 2016 ), providing employment and income at each level (Tieguhong, et. al. 2009; Suleiman et. al., 2017) thus they constitute a poverty trap, a safety net, or a potential resource for rural development and poverty alleviation. Unfortunately, this potential has not been exploited by rural women in Ekiti State, Nigeria, who were mostly unemployed, vulnerable and poor. Their impacts have only been felt indirectly in subsistent agriculture, and directly at the domestic domain. These women failed to take advantages in wrapping leaves in either their cultivation and / or trading. This study thus aimed to examine the economic potentials of wrapping leaves for rural women in Ekiti State, Nigeria.

\section{MATERIALS AND METHODS}

\section{Description of the Study area}

The study was carried out in Ekiti State (Lat. $7^{0} 25^{\prime}$ and $8^{0} 20^{\prime}$; Long. $5^{\circ} 00-$ $\left.6^{0} 00\right)$, Nigeria. The state consists of a land area of about $7000 \mathrm{~m}^{2}$ and over $70 \%$ of its 1.6 million inhabitants are farmers (Kayode et. al., 2016). Two climatic seasons abounds in the state, a rainy season from March to October and a dry season from November to February. The state is divided into three zones as Ekiti Central, Ekiti North and Ekiti South zones. Ekiti Central zone consists of Ado, Efon, Ekiti West, Ijero and Irepodun/Ifelodun Local Government Areas (LGAs), Ekiti North zone consists of Ido/Osi, Ilejemeje, Ikole, Oye and Moba LGAs and Ekiti South zone consists of Ekiti East, Ekiti South West, Emure, Gbonyin, Ikere and Ise/Orun LGAs.

\section{Sampling Technique and Data Collection}

A semi-structured questionnaire matrix was used to interview respondents in two selected LGAs from each of the zones. The LGAs selected were Ijero and Efon LGAs in Ekiti Central zone, Oye and Moba LGAs in Ekiti North zone, Ise/Orun and Ekiti South West LGAs in Ekiti South zone. Four rural communities were selected from each of the LGAs (Table 1). These communities were relatively far from urban influence. Though the Ekiti indigenous tribe with the same culture inhabits the State, yet sampling for this study was spread to cover the entire State. 


\section{Original Article}

Table 1: List of communities sampled in Ekiti State, Nigeria

\begin{tabular}{|c|c|c|c|}
\hline Zone & $\begin{array}{l}\text { Local } \\
\text { Governm } \\
\text { ent Area }\end{array}$ & $\begin{array}{l}\text { Commu } \\
\text { nities } \\
\text { Used }\end{array}$ & $\begin{array}{l}\text { No. of } \\
\text { Wom } \\
\text { en } \\
\text { Interv } \\
\text { iewed }\end{array}$ \\
\hline \multirow[t]{2}{*}{$\begin{array}{l}\text { Ekiti } \\
\text { Centra } \\
1\end{array}$} & Ijero & $\begin{array}{l}\text { Sakoro, } \\
\text { Ologboo } \\
\text { du, } \\
\text { Kajola } \\
\text { and Oke } \\
\text { Oko }\end{array}$ & 40 \\
\hline & Efon & $\begin{array}{l}\text { Araromi } \\
\text { Aladura } \\
\text {, odofin } \\
\text { and Aro }\end{array}$ & 40 \\
\hline \multirow[t]{2}{*}{$\begin{array}{l}\text { Ekiti } \\
\text { North }\end{array}$} & Moba & $\begin{array}{l}\text { Epe, Iro, } \\
\text { Alarasa } \\
\text { and } \\
\text { Osan }\end{array}$ & 40 \\
\hline & Oye & $\begin{array}{l}\text { Dakowa } \\
\text {, Igbo- } \\
\text { Ero, } \\
\text { igbo- } \\
\text { Ogbe } \\
\text { and } \\
\text { Oke- } \\
\text { Otin }\end{array}$ & 40 \\
\hline Ekiti & Ekiti & Aba & 40 \\
\hline \multirow[t]{2}{*}{ South } & $\begin{array}{l}\text { South } \\
\text { West }\end{array}$ & $\begin{array}{l}\text { Efon, } \\
\text { Elejofi, } \\
\text { Igunrin } \\
\text { and } \\
\text { Omipup } \\
\text { a }\end{array}$ & \\
\hline & Ise/Orun & $\begin{array}{l}\text { Afolu, } \\
\text { Kajola, } \\
\text { Obada } \\
\text { and } \\
\text { Ogbese }\end{array}$ & 40 \\
\hline
\end{tabular}

In each community, 10 women were selected randomly and interviewed. The interviews were focused, conversational and two-way in communication. The plant species used for wrapping as well as their abundance were identified. Species that could be seen within 20 minutes in the community were regarded as Very Abundant, those that could be seen within 40 minutes as Abundant, those that could take up to 60 minutes were regarded as Frequent while those of them that would take over 60 minutes to be seen as Rare. Respondents' indigenous knowledge on the rare but economic identified species was obtained to establish their sustainability potentials. Similarly, the economic potentials of the wrapping leaves species to women in the study area were determined. Voucher specimens of the identified wrapping species were collected and later identified and deposited to the herbarium of the Department of Plant Science and Biotechnology, Ekiti State University, Ado- Ekiti, Nigeria.

Group interviews were conducted in each community to determine group. Each group was made up of at least four rural women respondents, who had earlier participated in the individual interviews described above. Five group interviews were conducted in each LGA. Key informants, made up of wrapping leaves vendors, famers and officials of Community Development and Agriculture in the LGAs, officials of Agriculture Development Project were identified 


\section{Original Article}

and interviewed. Secondary information was obtained from records, journals and internet.

\section{RESULTS}

The demographic classification of the women respondents revealed that they were mostly from working age $(88 \%$, Table 2), adherents of the two major religion in the country, illiterates $(71 \%)$ and were well familiar with wrapping of foods and agricultural products. Table 3 shows that a total of 19 indigenous foods were associated with the use of wrapping leaves in the study area. These food cut across carbohydrates, proteins and fats though they were dominated by carbohydrates food.

Agricultural products usually wrapped with leaves are stated in Table 4. Nine products were observed. These products were usually of subsistence use rather than commercial. In addition, field observation revealed that they were being wrapped to enhance their transportation from farms. A total of 7 plant species, whose leaves were widely used for wrapping, were identified in the study area (Table 5). Five of these species were widely cultivated, though for purposes other than wrapping, in the study area. These species were $C$. esculenta, $M$. paradisiaca, M. sapientum, T. cacao and T. grandis. C. esculenta, M. paradisiaca and $M$. sapientum were cultivated for food, T. cacao for economic purpose and T. grandis cultivated mostly in government lands for industrial utilization. Leaf harvesting from $M$. macrostachyum and $T$. daniellii was obtained from their species growing in the wild. Information from key informants revealed that $T$. daniellii was being cultivated in commercial quantity in three locations in the state. T. daniellii ranked the highest on the scale of preference (Table 6) of preferred wrapping leaves by the respondents and it is the only species with marketable value.

Consequently, the gender specific roles on $T$. daniellii was determined. Women were observed to have dominated the issues involved on this species (Table 7). These include harvesting, products utilization, haulage and marketing. Marketing channels were observed to include producers (harvester), wholesalers (who buy directly from the producers), retailers (vendors who buy from the wholesalers) and the consumers (who buy directly from the vendors). Field observation revealed the existence of ready market for the leaves of $T$. daniellii in the urban areas.

Information from key informants revealed that wholesalers buy a medium-sized $T$. daniellii's leaf at an average cost of $0.5 \mathrm{Naira}$ and sell to the vendors at 3 Naira. Vendors sell at 5 Naira per leaf to the consumer (Table 8 ). Thus the table revealed that both the wholesalers and vendors make profits far in excess of the official monthly minimum wage in Nigeria. 
Table 9 revealed that the women respondents were familiar with the habit and ecology of this plant. Field observation revealed that though the rural women were conscious of the economic opportunity offered by investment in wrapping leaves, they were constrained by commitment to marriage, as they served as helping hands in farms to their husbands and numerous hindrances to convey the leaves to the urban areas for sale.

\section{DISCUSSION}

This study revealed that all women respondents were conscious of the use of leaves for wrapping food and agricultural products. Their socioeconomic classifications were not prerequisites to this consciousness. A variety of wrapping materials now flourish in the study area. These, in addition to leaves, included nylon, paper and aluminous foil. Indeed a study conducted in rural areas of Ghana revealed that the use of polythene nylon bags is fast replacing the traditional act of using leaves for wrapping food and packaging of agricultural products (Facciola, 1998). However, the indigenous residents' preference is still skewed to the use of leaves, which is regarded as culturally acceptable and medicinal. Recent initiative contends that the use of nylon and papers for wrapping foods have harmful health effects on humans as they contained substances that are harmful when ingested with food (Annon. 2014). Apart from the fact that the costs of these alternative wrapping materials were often beyond the reach of the resource-poor rural women, they were not even available for purchase in the rural areas of the state, The women are primarily saddled with food preparations, and hence they are well familiar with issues involving wrapping food with leaves. The leaf is an important non-timber forest product (NTFP). Studies have expressed that women are experts about NTFPs (Facciola, 1998). In the present study, a total of 19 indigenous food and 9 agricultural products were usually wrapped with leaves from 7 different plant species (Tables 3, 4 and 5).Two of these species, $M$. macrostachyum and $T$. daniellii, were presently rare and were not cultivated in the study area. Dependence on these species had been limited to those growing in the wild. However, $T$. daniellii was recognised as the species with market value (Table 6) thus confirming the previous description of the plant as an economic plant with versatile uses in Southern Nigeria (Shalom et. al., 2014).

The gender specificity test conducted on $T$. daniellii identified women as primarily responsible for harvesting leaves, utilizing of these products obtainable from the plant, transport of the products from farms and forest, and marketing of the products. All these tend to suggest that women possess the key into economic advantages that rely on this species. The examination of the market value 
of the species revealed that the species could offer considerable income in excess of the existing national monthly minimum wage in the country (Table 8). An examination of the women indigenous knowledge on the species revealed that the women were experienced on the habitat, ecology and propagation of the species, and hence inferred that women could cultivate this plant because it possesses economy of labour, suitable for cultivation in the study area, offer diverse economic advantages and easy for women to cultivate. The species was earlier observed to be perennial, monocotyledonous herb that propagates itself by rhizomes and forms an undergrowth of trees in its natural habitat. It has long, slender stalks that can grow up to two or three meters high, each bearing a single tough, ovoid shaped leaf of varying sizes depending on the plant's age and habitat (Makinde and Taiwo 2004). The plant grows throughout the hot, humid tropical rain forest and coastal zone of West Africa (Mansfeld 1986). Thus, the rural women possessed the knowledge required for the cultivation of this species, harvesting and marketing.

In conclusion, the goals of community development is to enrich and improve the quality of individuals and family life and assist in the economic sustainability of the family, particularly in situations where women, an important stakeholder in family issues, are employed in the informal sector and in the non-skilled areas. Thus, wrapping leaves offer greater opportunities for rural women in the informal sector to further support the economy of the family. Consequently, following recommendations were made:

a) Governments and nongovernmental organisations should enlighten women on the economic opportunity offered by wrapping leaves.

b) Women involvement in commercial cultivation of $T$. daniellii should be encouraged.

c) Efforts should be made to eliminate the activities of the middle womenwholesalers- from T. daniellii supply chain. These might include the organisation of rural women into co-operative groups that could be saddled with the provision of necessary haulage facilities that would convey the wrapping leaves to the urban areas for sale. This will further increase the income derivable by the rural women.

d) The Nigerian government should pay more attentions to the infrastructural development of the rural areas particularly through provision of rural roads.

\section{CONFLICT OF INTEREST}

The authors wish to state that there were no conflict of interest associated with this paper. 


\section{References}

Abdulmumeen, J. K., Lakpini, C.A.M., Alawa J.P., Mohammed, A. \& Nwanta, J.A. (2012). Evaluation of cassava as a protein supplement for sheep. Nig. J. Anim. Prod. 30 (1): 37- 46.

Annon . (2014). Is plastic food packaging dangerous?

https://www.choice.com.au/food-anddrink/food-warnings-and-

safety/plastic/articles/plastics- and food

Carr, M. (2008). Non-timber Foerst Products: Promoting Food Security and Economic Development. International Fund for Agricultural Development, Rome, Italy $44 \mathrm{pp}$.

Daniel, J.P. (2007). Managing the preservation of periodicals and newspapers. Bulletin des Bibliothèques de France 45(6): 83-87.

Endamana, D., Angu, K. A., Akwah, G. N., Shepherd, G. and Ntumwel, B. C. (2016). Contribution of non-timber forest products to cash and non-cash income of remote forest communities in Central Africa. Int For Rev 18(3):280-295

Facciola, S. (1998). Cornucopia 2: A source book of edible plants. Vista: Kampung Publications, 677pp.

Fieider, I. (1995). Packaging as an effective marketing tool, Pira International, Surrey: Institute of Food Technologists.

IFT. (1991). Guiding Principles for Optimum food safety oversight and regulation in the United States. Institute of Food Technologists. Food Tech. 52(5): 30

Kabuo, N.O., Asoegwu, S.N., Nwosu, J.N., Onuegbu, N. C., Akajiaku, L.O. \& Nwaimo, J. C. (2015). Assessment of leaf-type and number of leaves used in wrapping on the quality of "ugba" (fermented Pentaclethra macrophylla Benth seed). European Journal of Food Science and Technology 3(1): 11-23.

Karthikeyan, C., Veeraragavathatham, D., Karpagam, D. and Firdouse, S. A. (2009). Traditional tools in agricultural practices. Indian Journal of Traditional Knowledge 8(2):212-217.
Kayode, J. (2006). Conservation in Nigeria Perspective. Akolawole Press, Ado-Ekiti, 66pp.

Kayode J., Odesola, A. F., Ayeni, M. J., Awoyemi, S. B. (2016). Survey of Botanicals Used as Pesticides by the Rural Farmers of Ekiti State, Nigeria. International Journal of Biological Papers 1(2): 12-17.

Makinde, S.C.O. \& Taiwo, C. K. (2004). In situ population evaluation of Thaumatococcus danielli (Benth). ASSET Int. J., 2004, 3: 7580.

Mansfeld, R. (1986). Verzeichnis landwirtschaftlicher und gärtnerischer Kulturpflanzen. Berlin: Springer-Verlag, 1998pp.

Muncke, J. (2009). Exposure to endocrine disrupting compounds via the food chain: Is packaging a relevant source? Science of the Total Environment 407(16): 4549-4559.

Ojea, E., Loureiro, M. L, Alló, M. and Barrio, M. (2016). Ecosystem services and REDD: estimating the benefits of noncarbon services in worldwide forests. World Dev 78:246-261

Robertson, A. J. (2005). Consumer and their brands: developing relationship theory in consumer research. Journal of Consumer Research 24 (4): 343-373.

Schmidt, D. (2017). Cook with Banana Leaf. The Spruce https://www.thespruce.com/cookingwith- banana-leaf-3217239

Shalom, N., Chinedu, A. Y., Oluwadamisi, S. T., Popoola, B., David, J. \& Tamunotonyesia, E. (2014). Analyses of the Leaf, Fruit and Seed of Thaumatococcus daniellii (Benth.): Exploring Potential Uses. Pakistan Journal of Biological Sciences 17: 849-854.

Suleiman, M.S., Wasonga, V.O. and Mbau, J.S. (2017). Non-timber forest products and their contribution to households income around Falgore Game Reserve in Kano, Nigeria. Ecol Process 6, 23. https://doi.org/10.1186/s13717-017-00908 


\section{Original Article}

Tieguhong, J.C. and Ndoye, O. 2004. Development of trade and marketing of NWFPs for poverty alleviation in Africa. Workshop Paper Lessons Learnt on SFM in Africa. KSLA/AFORNET/FAO Project. Uppsala, Sweden. October. p. 67.
Tieguhong, J.C., Ndoye, O., Tchatat, M. and Chikamai, B. (2009). Processing and Marketing of Non-wood Forest Products: Potential Impacts and Challenges in Africa. Discov. Innov., (1), 60-65.

Table 2: Demographic Classification of Respondents in the study

\begin{tabular}{|c|c|c|c|c|c|}
\hline \multirow[b]{2}{*}{ Features } & \multirow[b]{2}{*}{ Description } & \multicolumn{4}{|c|}{ Proportion (\%) of Respondents* } \\
\hline & & $\mathrm{EC}$ & EN & ES & $\begin{array}{c}\text { Average } \\
\text { Total }\end{array}$ \\
\hline \multirow[t]{2}{*}{$\begin{array}{l}\text { Age } \\
\text { (Yrs) }\end{array}$} & $20-60$ & 82 & 96 & 87 & 88 \\
\hline & $>60$ & 18 & 4 & 13 & 12 \\
\hline \multirow[t]{2}{*}{ Religion } & Christianity & 67 & 54 & 62 & 74 \\
\hline & Islam & 33 & 46 & 38 & 26 \\
\hline \multirow{2}{*}{$\begin{array}{l}\text { Literacy } \\
\text { status }\end{array}$} & Literate & 35 & 22 & 30 & 29 \\
\hline & Illiterates & 65 & 88 & 70 & 71 \\
\hline
\end{tabular}

* \% calculated to the nearest whole numbers

Table 3: Foods wrapped with leaves in the sampled area of Ekiti State, Nigeria

\begin{tabular}{|c|c|}
\hline Food & Description \\
\hline Aadun & $\begin{array}{l}\text { This is prepared from maize. The maize is roasted and then ground into } \\
\text { powder with little pepper and mixed with palm oil. It is then wrapped in } \\
\text { leaves. }\end{array}$ \\
\hline Abari & This is prepared from grinded maize that is wrapped in leaves and steamed. \\
\hline Adalu & This is a mixture of cooked maize and beans, then wrapped in leaves \\
\hline Agbado-Egbo & This is made of cooked maize and wrapped in leaves \\
\hline Amala & $\begin{array}{l}\text { This is made from powdered form of plantain or yam or cassava and then } \\
\text { wrapped in leaves. }\end{array}$ \\
\hline$E b a$ & $\begin{array}{l}\text { This is made from fermented, powdered form of cassava and then wrapped } \\
\text { in leaves. }\end{array}$ \\
\hline Eepa-kooko & $\begin{array}{l}\text { This is prepared from cooked cocoyam, sliced and sundried, it is then } \\
\text { wrapped in leaves and re-cook after which palm-oil is added. }\end{array}$ \\
\hline Egute & $\begin{array}{l}\text { This is prepared from maize. The maize is roasted and then ground into } \\
\text { powder with little pepper and mixed with palm oil. It is then wrapped in } \\
\text { leaves. }\end{array}$ \\
\hline Eko & This is solid pap that is wrapped in leaves \\
\hline Ekuru & $\begin{array}{l}\text { This is prepared by removing the seeds coats of beans, then the seeds are } \\
\text { grinded, wrapped in leaves and then steamed. }\end{array}$ \\
\hline Ewa & This is made up of cooked beans and then wrapped in leaves \\
\hline Fufu & This is made from fermented cassava, grinded and cooked. It is later \\
\hline
\end{tabular}




\section{Original Article}

wrapped in leaves

Iresi This is cooked rice that is later wrapped in leaves

Iru This is a soup condiment made from fermented seeds of Locust Bean

Isu This is made up of cooked or roasted yam and later wrapped in leaves

Iyan This is made by pounding yam and later wrapped with leaves

Moinmoin This is prepared by removing the seeds coats of beans, then the seeds are grinded, missed with palm oil, wrapped in leaves and then steamed.

Monmon This is prepared by grinding plantain, wrapped in leaves and steamed Ogiri This is a soup condiment made from melon

Table 4: Agricultural products wrapped with leaves in the sampled area of Ekiti State, Nigeria

\begin{tabular}{ll}
\hline Agricultural products & Description \\
\hline Ata & These are the fruits of pepper used mostly for culinary purposes \\
Efo & These are vegetables used for soup preparations \\
Eyin & These are the seeds of palm oil used for culinary purposes \\
Ikan & These are fruits of some vegetables used for culinary purposes \\
Ila & These are fruits of okra crop \\
Obi & These are seeds of Kola used as stimulant \\
Orogbo & These are seeds of Bitter Kola used as stimulant \\
Osun & Mushrooms used for culinary purposes \\
Tomanti & Tomatoes fruits \\
\hline
\end{tabular}

Table 5: Identified plant species whose leaves are used for wrapping in the sampled area of Ekiti State, Nigeria

\begin{tabular}{|c|c|c|c|c|}
\hline \multicolumn{2}{|c|}{ Plant Species } & \multirow[b]{2}{*}{ Type } & \multicolumn{2}{|c|}{ Wrapping Value } \\
\hline Botanical Name & $\begin{array}{l}\text { Vernacular } \\
\text { Name }\end{array}$ & & Foods & Agric. Product \\
\hline $\begin{array}{l}\text { Colocasia } \\
\text { esculenta }\end{array}$ & Kooko & Fresh & $\begin{array}{l}\text { Ata, Efo, Eyin, } \\
\text { Ikan, Ila }\end{array}$ & None \\
\hline $\begin{array}{l}\text { Megaphrymium } \\
\text { macrostachyum }\end{array}$ & Gbodogi & Fresh & $\begin{array}{l}\text { All foods in } \\
\text { Table } 3\end{array}$ & $\begin{array}{l}\text { All products in } \\
\text { Table } 4\end{array}$ \\
\hline Musa paradisiaca & Ogede-Agbagba & Fresh & $\begin{array}{l}\text { All foods in } \\
\text { Table } 3\end{array}$ & $\begin{array}{l}\text { All products in } \\
\text { Table } 4\end{array}$ \\
\hline & $\begin{array}{l}\text { Dried and } \\
\text { moistened }\end{array}$ & & $\begin{array}{l}\text { All foods in } \\
\text { Table } 3\end{array}$ & $\begin{array}{l}\text { All products in } \\
\text { Table } 4\end{array}$ \\
\hline Musa sapientum & Ogede-Wewe & Fresh & $\begin{array}{l}\text { All foods in } \\
\text { Table } 3\end{array}$ & $\begin{array}{l}\text { All products in } \\
\text { Table } 4\end{array}$ \\
\hline & $\begin{array}{l}\text { Dried and } \\
\text { moistened }\end{array}$ & & $\begin{array}{l}\text { All foods in } \\
\text { Table } 3\end{array}$ & $\begin{array}{l}\text { All products in } \\
\text { Table } 4\end{array}$ \\
\hline Tectonia grandis & Tiiki & Fresh & None & $\begin{array}{l}\text { All products in } \\
\text { Table } 4\end{array}$ \\
\hline
\end{tabular}




\section{Original Article}

\begin{tabular}{lllll}
\hline $\begin{array}{l}\text { Thaumatococcus } \\
\text { daniellii }\end{array}$ & Eran & Fresh & $\begin{array}{l}\text { All foods in } \\
\text { Theobroma caca } 3\end{array}$ & $\begin{array}{l}\text { All products in } \\
\text { Table } 4\end{array}$ \\
& Koko & Dried & Ata, Ikan, Ila & $\begin{array}{l}\text { Aadun, Iru, } \\
\text { Ogiri }\end{array}$ \\
\hline
\end{tabular}

Table 6: Determination of rare but economic wrapping leaves in the sampled area of Ekiti State, Nigeria

\begin{tabular}{lll}
\hline Feature & Description & Species \\
\hline Cultivation status & Cultivated & C. esculenta, M. paradisiaca, M. sapientum, \\
& Not-cultivated & T. grandis, T. cacao \\
Abundance & Very Abundant & M. paradisiaca, M. sapientum \\
& Abundant & C. esculenta, T. cacao \\
& Frequent & T. grandis \\
& Rare & M. macrostachyum, T. daniellii \\
Scale of preference & & 1. T. daniellii $(100 \%)$, \\
& & 2. M. paradisiaca and M. sapientum $(94 \%)$ \\
Marketable leaf species & & T. daniellii \\
\hline
\end{tabular}

Table 7: Gender specificity in T. daniellii in the sampled area of Ekiti State, Nigeria

\begin{tabular}{lll}
\hline Roles & Description & Dominating Gender \\
\hline Harvesting & Leaf (For wrapping) & Female \\
Products & Stalks (For mat making) & Female \\
Haulage & & Female \\
Marketing & Wholesale & Female \\
Cultivation & Retail & Female \\
\hline
\end{tabular}

Table 8: Economic potential of T. daniellii's leaf in the sampled area of Ekiti State, Nigeria

\begin{tabular}{ll}
\hline Description* & \\
\hline Average cost of medium-sized leaf & 0.5 Naira \\
Average cost of medium-sized leaf to Vendor & 3.5 Naira \\
Average cost of medium-sized leaf to Consumer (in the State capital) & 5.0 Naira \\
Average number of leaf sold per day /Vendor (in Main Market) & 850 Pieces \\
Average income generated / day/ Vendor & 1275 Naira \\
Average income generated /28 days/ Vendor & 35700 Naira \\
Minimum wage in Nigeria /Month (at July 2018) & 18000 Naira \\
\hline
\end{tabular}

*1Naira $=0.0028$ US Dollar (As at July 2018) 


\section{Original Article}

Table 9: Indigenous knowledge (IK) of women respondents on T. danielli in the sampled area of Ekiti State, Nigeria

\begin{tabular}{|c|c|c|}
\hline Respondents' IK & Observation & Inference \\
\hline It is a herb plant & $\begin{array}{l}\text { The women are used to tending } \\
\text { herbs }\end{array}$ & Women could cultivate this \\
\hline It is perennial & $\begin{array}{l}\text { Capable of yielding dividend } \\
\text { continuously }\end{array}$ & $\begin{array}{l}\text { Economy of labour abounds } \\
\text { in cultivating this plant }\end{array}$ \\
\hline Thrive in forest & $\begin{array}{l}\text { Study area is located in forest } \\
\text { vegetation }\end{array}$ & $\begin{array}{l}\text { Suitable for cultivation in } \\
\text { study area }\end{array}$ \\
\hline Propagated from stem & Planting materials are available & $\begin{array}{l}\text { Planting the species is easy } \\
\text { for woman to carry out }\end{array}$ \\
\hline Withstand fire annually & $\begin{array}{l}\text { Underground part brings forth } \\
\text { new individuals after fire }\end{array}$ & Ensures economic returns \\
\hline
\end{tabular}

